\title{
AZ IPAR SZEREPE A ,,SZOCIALISTA” GAZDASÁG- ÉS TERÜLETFEJLESZTÉSI POLITIKÁBAN
}

\author{
(The role of industry in the ,socialist" economic- and regional \\ development policy)
}

\section{BARTA GYÖRGYI}

Már közhely számba megy az a megállapítás, amely a szocialista gazdaságfejlesztést az ipar, ezen belül is a nehézipar fejlesztésével azonosítja. Teljesen nyilvánvaló, hogy a területfejlesztési politika is a szocialista gazdaságfejlesztés elképzeléseit vette át; a térbeli különbségek kiegyenlítését az elmaradott térségek iparfejlesztésével látta elérhetổnek. Gondoljunk csak a 60-as évek elején megfogalmazott célkitû́zésekre: Budapest szelektív fejlesztésére az iparkitelepítéssel és az iparfejlesztés adminisztratív megakadályozásával, az Alföld és Dél-Dunántúl iparosítási programjára, vagy a szénbányászati térségek racionalizálási, ipartelepítési terveire.

Ezek az iparfejlesztésre alapozódó területfejlesztési programok jórészt csak az extenzív irányú bơvítést tartalmazták, pontosabban a munkahelyek számának szaporítására vagy felszámolására /Budapest szelektiv fejlesztésének igénye a fôvvárosban a már jelentkezó munkaeróhiány idôszakára esett/ korlátozódtak. Nem fogalmazták meg azt a célt, hogy a fejleszteni kívánt területre korszerũ ipari struktúra kerüljön. Ennek tulajdonítható, hogy például az iparosítási programon , átesett" Alföld ma is az elmaradott térségek közé tartozik. Ugyancsak teljességgel hiányzott a területfejlesztési programokból az irányítás-ellenốrzés-döntéshozás funkcióinak decentralizálására irányuló törekvés. A területfejlesztési program nem vette figyelembe, hogy az elmaradott térségekbe vagy a közép- és kisméretũ településekbe telepített ipari munkahelyek túlnyomó része távoli nagyvárosi központú vállalatok részlegeihez tartozik (1. táblázat).

Az egyes térségekre jellemzơvé vált , ,részlegipar" pedig gyökértelen maradt, nem gerjesztett további fejlesztést a térségben, és helyzete gyorsan elbizonytalanodott a kedvezôtlenné váló közgazdasági helyzetben. Nem véletlenül jellemezték ezt az iparosítási programot gyarmatosításként. Hangsúlyozni kell azonban, hogy a területfejlesztési programok csupán megfogalmazott és jórészt papíron maradt programok voltak. A területi politika valójában nem érvényesülhetett az ágazati politika mellett, fóképpen nem azzal szemben. A területfejlesztés nem rendelkezett önálló financiális eszközökkel. (Például az 1970-es években létrehozott Területfejlesztési Alap az ipari beruházásoknak mindössze 1\%-át tette ki, és az összes beruházásoknak csak 4-5\%-át orientálta. Néhány év elmúltával a Területfejlesztési Alap meg is szűnt. Eredményeket, sikereket akkor könyvelhetett el, amikor a területi politika célkitüzései teljességgel egybeestek az iparfejlesztési programmal.) Az extenzív fejlesztés utolsó, konjunkturális fázisában, az ipar a szabad erôforrások, elsốsorban a munkaerô, utáni vadászatban jutott el az ország eldugott csücskeibe is. A területi dekoncentráció mértékét már a szakemberek is vitatták, és ốk maguk szứkítették a fejlesztésre kijelölt települések körét.

Nem véletlen, hogy a területfejlesztési program nem foglalkozott az irányítás területi decentralizációjával, hiszen az iparpolitika is újabb és újabb centralizációs hullámot indított el, a hatvanas évek közepén egyharmadával csökkentve a vállalatok addigi számát, és a késôbbiekben is támogatva a nagyvállalatok beolvasztási törekvéseit. 
Barta Györgyi: Az ipar szerepe a „szocialista” gazdaság- és területfejlesztési politikában.

Tér és Társadalom, 5. 1991. 4. 37-50. p.

$38 \quad$ Barta Györgyi

TÉT 1991-4

\section{TÁBLÁZAT}

A megyén kívüli központokból irányitott ipar a dél-alföldi megyék iparában, 1982

(The role of industry managed from centres outside the county in the industry of counties in the Southern Great Plain, 1982)

\begin{tabular}{lccc}
\hline 4.Megyék & 1. & 2. & 3. \\
\hline Bács-Kiskun & 59,1 & 52,4 & 88,5 \\
Békés & 47,1 & 33,1 & 70,3 \\
Csongrád & 30,3 & 24,2 & 80,0 \\
Szolnok & 34,5 & 26,7 & 77,4 \\
\hline
\end{tabular}

1 = A megyén kívüli központokból irányított dél-alföldi ipari telephelyeken dolgozók aránya a megye összes ipari dolgozójából (\%)

2 = A budapesti vállalatok helyi telephelyein dolgozók aránya a megye ipari dolgozói között (\%)

3 = A megyén kívüli központokból irányitott iparban a budapesti részarány (\%)

Forrás: A KSH nem publikált ipari telephelyi adatai, 1982.

1. Proportion of workers at work places managed from centres outside the county in all the industrial workers of the county (\%)

2. Proportion of workers at he local seats of Budapest-centred companies in all industrial workers of the county (\%)

3. Share of Budapest in ndustry managed from centres ontside the county (\%)

4. Counties

Végül is tehát, az iparpolitikának megfelelôen és a területfejlesztési politikának nem ellentmondóan, az ipari termelés soha nem látott méretekben terjedt szét az ország területén, az irányítás-döntéshozás viszont egyre centralizáltabbá vált. A centralizáció nemcsak az irányításra, hanem a termelés dinamikus elemeire, illetve a központok mứködéséhez nélkülözhetetlen, némileg korszerúbb infrastruktúrára is vonatkozott.

A szellemi potenciál, és az iparhoz szorosan hozzátartozó tercier ágazatok területi centralizációja ennek az iparfejlesztési politikának volt az egyenes következménye. Még valamit érdemes megjegyezni: az ipari potenciál döntố része természetesen a nagyobb városokba összpontosult (egy akkori vizsgálatunk 78-ra tette azoknak a településeknek a számát, melyek nemcsak az ipari termelés, hanem az irányítás szempontjából is jelentôseknek voltak tekinthetốk). Hogy valójában az iparosodó települések, térségek között milyen különbségek alakultak ki, azt legkevésbé sem a területfejlesztési politika határozta meg, hiszen - mint említettük - a területfejlesztéssel foglalkozó intézmények meglehetôsen szerény eszközökkel rendelkeztek.

A térbeli gazdasági differenciálódás elsôsorban az ipari minisztériumok nagyberuházásainak (amelybe lényeges beleszólása volt az erôs alku-poziciókkal rendelkezõ nagyvállalatoknak) és a vállalatok saját fejlesztéseinek, valamint az állami támogatási és elvonási rendszernek a függvénye volt.

A redisztribuciós folyamatnak, mely a jól mứködổ vállalatoktól elvonta az átlagon felüli nyereséget, a ráfizetéses, gazdaságtalan vállalatokat pedig - legalábbis fennmaradásuk mértékéig - támogatta, területi szintũ kiegyenlítõ illetve differenciáló hatását még máig sem ismerjük pontosan. Az azonban nyilvánvaló, hogy ezek a beavatkozások, nem pedig a területfejlesztésre fordítható beruházások, játszották a meghatározó szerepet a területi különbségek kialakulásában. 


\section{Az ipar jelenlegi összehúzódása}

Az ipari munkahelyek, az iparban foglalkoztatottak száma jelenleg fogy. Ez a tendencia nem újkeletư: már a 60-as évek végétôl kezdốdôen regisztrálták a budapesti ipari létszám csökkenését, ezt követték a nagyvárosok és az iparilag fejlett térségek, majd a visszaesés jellemzôvé vált az ország minden részére, beleértve a kis és nagy településeket egyaránt.

A létszám apadásának azonban különbözố okai voltak: a 70-es években és a 80-as évek elején az ipart a gazdaság többi szektoránál jobban sujtó munkaerôhiány (pontosabban más ágazatok vonzóbb munkafeltételei) vezetett a létszám csökkenéséhez. A helyzet a 80-as évek végétól megfordult. A gazdaságtalanul termelố vagy eladhatatlan termékeket gyártó vállalatokat bezárják vagy a termelés méreteit, következésképpen a munkahelyek számát is drasztikusan csökkentik. Ma az iparban tartják nyilván a legnagyobb arányú munkanélküliséget.

1982 és 1990 között közel 300 ezer fôvel, vagyis 20\%-kal (1989 és 1990 között 106 ezer fôvel) csökkent az iparban foglalkoztatottak száma. Az ipar összehúzódása elóször a ,,szocialista” keretek között túlfejlesztett bányászatban és kohászatban indult meg (24,2\%-kal, illetve 21,1\%-kal csökkent e két ágazatban foglalkoztatottak száma 1988 és 1990 között). Majd a KGST, fóleg a szovjet piac összeomlása vezetett a gépipar és a vegyipar $40 \%$-os termeléscsökkenéséhez, illetve létszámleépítéséhez (a gépiparban 80 ezer fóvel).

A termelésvisszaesés, az infláció, a munkanélküliség végülis a hazai fogyasztás erốteljes beszúkülését eredményezte, amely a könnyứ-és az élelmiszeripar termeléscsökkenéséhez, illetve újabb elbocsátásokhoz vezetett. A többszázezer ipari munkahely felszámolásával a betöltetlen állások egyre inkább összezsugorodó kínálata áll szemben. 1990 októberében kevesebb mint 17 ezer állást kínáltak.

Az ipar visszaszorulása egyben területi különbségeket is jelez; vannak ugyanis olyan térségek, városok, ahol a munkanélküliség mértéke és gyors növekedése miatt területi válságról beszélhetünk (1990-ben 10\%-ot meghaladó munkanélküliség alakult ki Nyírbátorban, Szerencsen, Vásárosnaményben, Fehérgyarmaton, Mezớkovácsházán, Csengeren és Biharkeresztesen - valamennyi település az ország keleti részén fekszik) (1. ábra).

Kétségtelen, hogy az iparban az elmúlt években is tömegével nyíltak új vállalatok; még a fentebb említett válságtérségekben is növekszik a vállalatok, az ipari társulások, köztük fóként a kft-ék száma. Az új vállalatalapítások Budapestre és a környezó megyékbe összpontosulnak (2. ábra). 

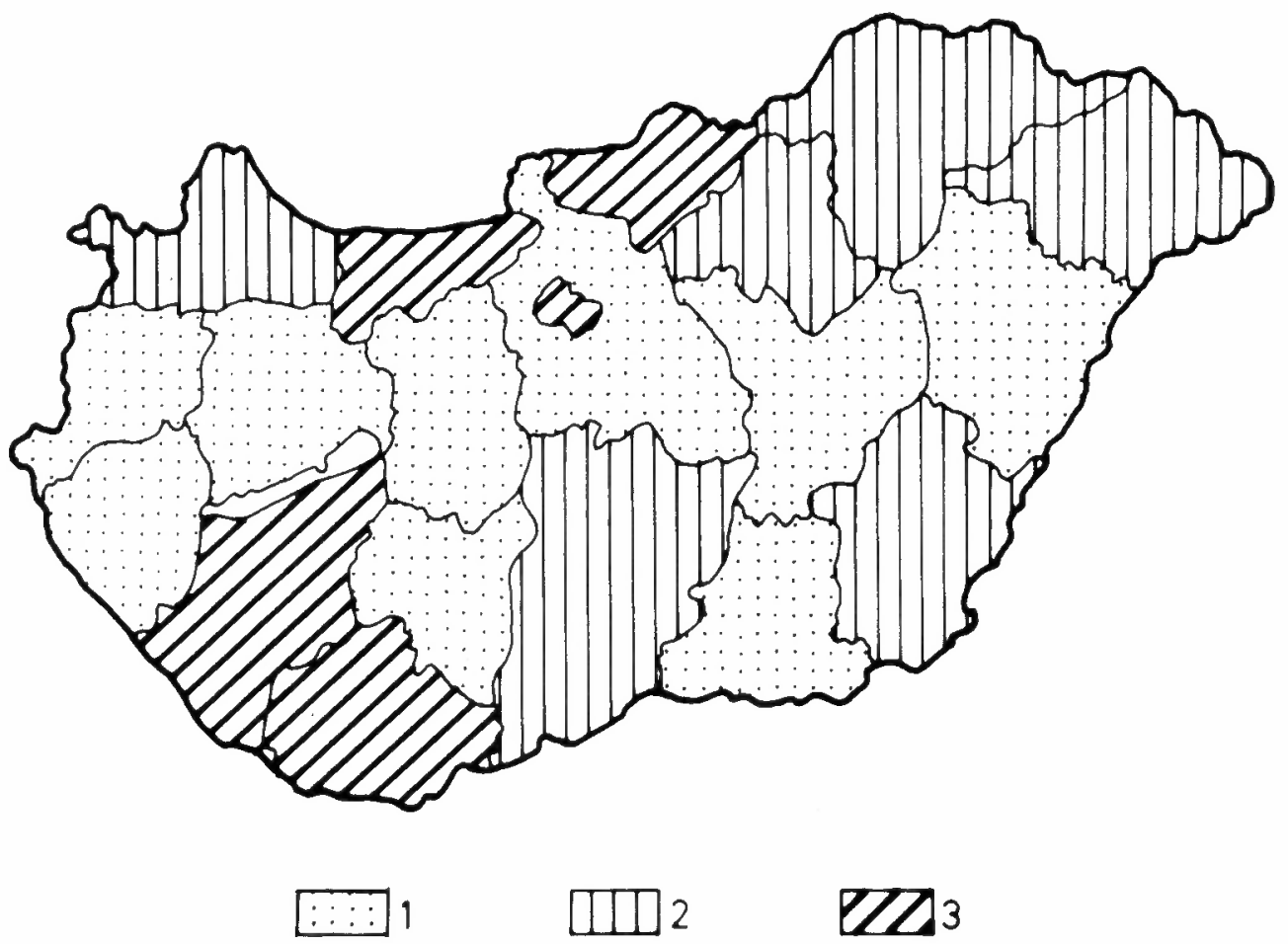

1. ÁBRA

Az ipari foglalkoztatottak számának csökkenése 1982-1990 között (Decrease of industrial employees between 1982-1990)

Jelkulcs:

$1=10,1-15,0 \%$

$2=15,1-20,0 \%$

$3=20,1-\%$ 


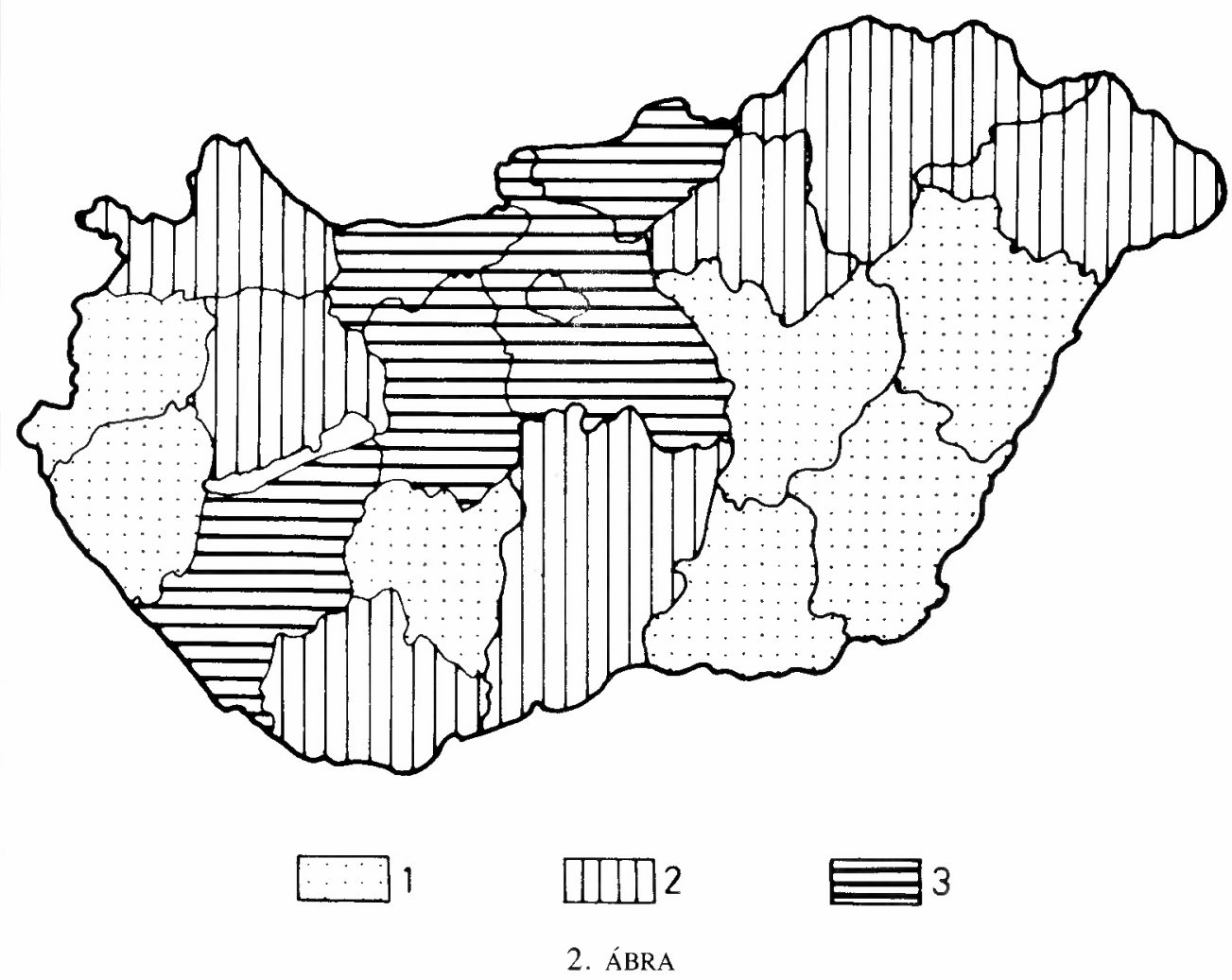

Az ipari szervezetek számának növekedése 1982-1990 között

(The increase of industrial organizations between 1982-1990)

Jelkulcs:

$1=300,0-400,0$ fổ (people)

$2=400,0-500,0$ fó

$3=500,0-$ fố 
Az új vállalatok nagyrésze kisméretú, amelyek lehetnek ugyan sikeresek, de semmiképpen sem nyújtanak elegendố munkahelyet a nagyvállalatoktól tömegesen elbocsátott munkaerố számára (számításaink szerint két év alatt, vagyis 1989 és 1990 között, az 5 ezer fổnél többet foglalkoztató iparvállalatoktól közel 35 ezer fôt küldtek el). Az ipar összehúzódását nemcsak a létszámcsökkenés bizonyítja, hanem a termelés abszolút és relatív visszaesése is (2. és 3 . táblázat).

\section{TÁBLÁZAT}

Az ipari hozzáadott érték (GDP) tényleges és várható változása (Real and expected changes in industrial GDP)

1. Év 1988

1989

1990

1991

1992

1993

1994
2. Mrd Ft(összehasonlító áron)

355,0

344,1

312,1

286,2

295,9

Forrás: Ipar- és kereskedelempolitikai koncepció, (1991-1994) IKM, Budapest, 1991.

1. Year

2. Billion HUF (at comparable prices)

3. TÁBLÁZAT

Az ipar részesedése a gazdaság bruttó termelési értékéból, \% (Share of industry from GDP)

\begin{tabular}{lcc}
\hline 1. Ágazat & 1989 & 1990 \\
2. Ipar+építôipar & 62,9 & 60,2 \\
3. Mezốgazdaság & 15,3 & 14,6 \\
4. Egyéb & 21,8 & 25,2 \\
\hline & 100,0 & 100,0 \\
\hline
\end{tabular}

Forrás: Ipari és kereskedelmi koncepció, Az 1988-90-es évek értékelése, IKM, Budapest, 1991.

\section{Sector}

2. Industry + construction industry
3. Agriculture

4. Other

Nem kétséges, hogy a magyar gazdaság új struktúrája van kialakulóban, melyben a szolgáltatásokat - ezeken belül is a gazdasági szolgáltatásokat - a dinamikus növekedés jellemzi, az ipar pedig folyamatosan veszít a súlyából. Jelentôs változások indultak el, melyek nyilvánvalóan át fogják formálni a magyar gazdaság, az ipar múltbeli térszerkezetét. E folyamatnak azonban jelenleg még csak az elsố, szerény jeleit tapasztalhatjuk. Az ipari foglalkoztatottak területi meg- 
oszlásának arányai alig változtak a közelmúlt éveiben (az 1980-as állapothoz viszonyítva); csökkent Budapest, Borsod-Abaúj-Zemplén és Komárom megye részaránya, mégpedig eléggé egyenletes mértékben a többi megye javára. 1985 és 1989 között ugyanis - tulajdonképpen nem meglepố módon - az alföldi, a nyugat-magyarországi kevésbé iparosodott megyék, illetve Budapest termelési eredményei növekedtek.

Az 1990. évi vállalati , ,toplista" (Figyelố, 1991. július) új jelenségekre hívta fel a figyelmet: a legeredményesebb 25 iparvállalat (vagyonarányos eredmény alapján) között jóformán nem szerepeltek nagyvállalatok (kivételt egyedül az OKGT jelentett, amely elsố helyen állt a nettó árbevételt tekintve, eredményessége alapján pedig hatodik volt). A 25 vállalat közül $13 \mathrm{az}$ élelmiszeriparhoz, 5 a könnyưiparhoz, és csak 3 tartozott a gépiparhoz (többségük távol áll a csúcsiparoktól). Az említett 25 legsikeresebb vállalat közül csupán hétnek van a központja Budapesten.

Budapest iparirányító szerepe - a több telephelyes vállalatok központjai és vidéki telephelyei módosuló arányainak, illetve az új vállalkozásoknak tulajdoníthatóan — csökken. Ugyanakkor azonban még nem fedezhetốk fel a jelei más ipari központok köré formálódó új ipari körzetek kialakulásának. Budapest ,,centrum”-funkciója javarészt egyre inkább abban nyilvánul meg, hogy a gazdaság új motorja, nevezetesen a szolgáltató szektor, itt múködik a legdinamikusabban: Budapesten dolgozott 1989-ben a szolgáltató szektorban foglalkoztatottaknak 36,6\%-a, a nem anyagi jellegư szolgáltatásban pedig 42\%-a. Míg Budapesten a szolgáltatásokban 2,5-szer többen dolgoznak, mint az iparban, addig Fejér, Komárom, Veszprém, Borsod-Abaúj-Zemplén, és Nógrád megyében az iparban dolgoznak többen, mint a szolgáltatások területén. A csúcstechnológiát képviselố korszerú iparágazatok, melyek a dinamikus kisvállalkozások, és a vegyes vállalatok, fốként Budapesten és környékén tevékenykednek. Ebben nagy szerepe van a lényegesen fejlettebb szolgáltató szektor itteni jelenlétének is.

\section{Az ipar területileg differenciált, de általános összehúzódásából levonható következtetések}

Hosszú évtizedeken keresztül — mondhatni a legutolsó idókig — az ipar a gazdaság motorja volt Magyarországon. A kérdést a következốképpen kell feltennünk: Vajon Magyarország gazdasági fejlódése - a fejlett világra jellemzô tendenciákat követve - eljutott-e már az ún. ,,posztindusztriális” korszakba, amikoris az ipar természetszerúleg fokozatosan visszaszorul? Vagy nem másról van-e szó, mint a szocialista gazdaság átfogó válságáról, illetve a két rendszer közti ,„csere” által kiváltott átmeneti visszaesésról? Ez utóbbi esetben elképzelhetổ, hogy a várt gazdasági stabilizálódás egyben az ipar újbóli fellendülését is magával hozza?

A kérdés érdemleges megválaszolása nem lehet közömbös a területfejlesztési politika szemszögéból sem, hiszen ennek egyben arra is választ kellene adnia, hogy az ipar milyen szerepet tölthet be a jövốben a területfejlesztésben. 


\section{A posztindusztriális fejlódésról}

A 70-es évek második felétôl gyakorlatilag az összes fejlett tốkés ország szenvedett a növekvố munkanélküliségtốl, a munkahelyek egyre nagyobb számú megszũnésétốl, és a krónikus inflációtól. E folyamatok váltották ki a gazdaság átstruktúrálódását és tömeges térbeli átrendezôdését. Az 1970-es években az USA ipari kapacitásának hatalmas méretũ racionalizálása indult meg, és hasonló folyamatok zajlottak le Anglia régi ipari térségeiben is. Az Észak-Amerikában és Nyugat-Európában kialakult gazdasági átrendezôdést sokan a dezindusztrializáció folyamataként értékelték, amit gyakorlatilag a tradicionális iparágak jelentốs visszaszorulásával vagy eltúnésével magyaráztak. Különösen látványos átrendezổdés volt nyomon követhetổ a nagyvárosi gazdaságokban. A dezindusztralizáció gondolata azokat az elméleteket erôsítette, amelyek a nagyváros életét és fejlődését függetlenítették az ipar szerepétôl.

A 80-as években azonban már az új növekedési hullám jelei voltak tapasztalhatók. Új iparok honosodtak meg, amelyek tevékenysége a csúcstechnológia alkalmazására épült. Eközben a nagyvárosok hivatali és szolgáltató funkciója is robbanásszerûen bổvült, és nem egy nagyvárosban e funkciók uralják ma a foglalkoztatás fóbb típusait.

Kétirányú, egymással szembehelyezkedố és egymással vitázó elméletrendszer bontakozott ki. Az egyik hipotézis a posztindusztriális társadalomról, és ennek megfelelôen a posztindusztriális városról beszél. E nézet szerint a gazdasági szervezet új információs termelési módja alakul ki. Nézetük szerint a jelenkori kapitalizmus minőségileg új szakaszába lépett, aminek jelei a gazdaságban az üzleti és szolgáltató funkciók uralkodóvá válása, a bank- és pénzügyi tevékenység tömegessé válása, az értelmiség növekvố szerepe, az információáramlás kibôvülése. E jelek különösen gyorsan szaporodnak a nagyvárosok életében. A gazdaság városi fejlődésének motorja tehát már nem az ipar, hanem más, attól független tevékenységek.

A másik nézet szerint viszont az ipari termelési rendszer változása játszik alapvetổ szerepet a nagyvárosi központok növekedésében, az újratermelésben, a stagnálásban vagy a visszaesésben. A modern metropolisz létrejötte a kapitalista ipari termelés logikájából következik. Kétségtelen, hogy a gazdaság, a nagyváros struktúrája átalakult, a tradicionális ipari ágazatok szerepe lényegesen visszaszorult, azonban az új tevékenységek túlnyomó része (adminisztráció, bank, biztositás, a pénzügyi szolgáltatások, a hirdetés stb.) ráépül az ipari termelés világméretû́ rendszerére. Az ipari termelés új szervezeti rendszerét egy új, funkcionálisan hierarchikus struktúra létrejötte, a rendszer növekvố rugalmassága, és a vállalati szervezeti formák változatossága jellemzi. (Beszélhetünk tehát a kapitalista ipar késối korszakáról - minôségileg megkülönböztetve ezt a korábbi idôszak jellemzôitốl -, de e korban is az ipar lesz a gazdaság és egyben a nagyváros fejlốdésének motorja.)

A válság - a szocialista gazdaság (ipar) válsága - az ipar nehézségei az átmeneti idószak nehézségei

Könyvtárnyi irodalom szól a szocialista gazdasági modell életképtelenségérốl, szükségszerũ összeomlásáról. A válságot külsố és belsổ körülmények egybeesése váltotta ki: az autarch szemléletũ, a nehézipar dominanciáján alapuló iparfejlesztési politika, a szervezeti rendszer merevsége és centralizációra való hajlama, az innováció-, a verseny hiánya, az állami tulajdon visszahúzó szerepe stb., illetve az önálló kontextust alkotó szocialista világrendszer összeomlá- 
sa, a KGST megszünése, továbbá a szovjet piac beszúkiulése és bizonytalanná válása, a szocialista pénz- és árrendszer felbomlása stb.

Az új társadalmi-gazdasági rendszerben, amikor is Magyarország, a többi közép-keleteurópai országgal együtt, közvetlen kapcsolatba került a fejlett piacgazdaságokkal, a szocializmusból örökölt ipar nem állja a versenyt a világpiacon és - a szükséges feltételek hiányában - nem, vagy csak roppant nehézségek közepette képes a megújulásra.

Az ipar jelenlegi technikai-technológiai szintjén elỏállított termékek egyre kevésbé eladhatók. A Szovjetúnió, a legfóbb eddigi vásárló, fizetésképtelen, de az is kétséges, hogy most már - konvertibilis valutáért és a világpiachoz igazodó árakon - egyáltalán keresné-e a magyar árukat. A kelet-európai országok vásárlóereje is meggyengült, a kétoldalú kereskedelem kiszélesítését nehezítik a párhuzamos kapacitások. (Figyelembevéve az adottságokat és az elmúlt rövid időszakot, a magyar ipar jelentôs eredményeket könyvelhetett el a konvertibilis export növelésében. A rubelviszonylat 1987. évi 50,4\%-os aránya 1990-ben 27\%-ra csökkent, a konvertibilis viszonylat 49,6\%-os aránya ennek megfelelóen $73 \%$-ra nốtt. Vagyis a konvertibilis export volumene 1987 és 90 között 41\%-kal nőtt.)

Az ipart tehát új vágányokra kellene állítani, ehhez azonban javarészt hiányzanak a szükséges eszközök. Nyomasztó a hazai tôkehiány (illetve a tôkéhez való hozzájutás követelményei a többség számára teljesíthetetlenek), a külföldi tốke beáramlását pedig kedvezôtlen külsố és belsô körülmények gátolják. Az állam korábbi megkülönböztetett figyelme az ipar iránt megszứnt, a gyötrố államadósság, a költségvetés növekvô hiánya és a gazdaság más területein is halmozódó feszültségek miatt. Az államnak egyébként - a redisztribuciós rendszer egyre szúkülố mozgástere következtében - nem is lenne a korábbiakhoz hasonló lehetôsége az ipar támogatására. (Az iparban 1989 és 1990 között a költségvetési elvonások kb. 10\%-kal növekedtek, a támogatások 12\%-kal csökkentek. 1990-ben 100 millió Ft elszámolt elvonásra csupán 4,6 millió Ft támogatás jutott. Az utóbbi évek ipari beruházásaiban erốteljesen csökkent a központi beruházások aránya, kisebb mértékben a vállalatok, nagyobb mértékben a lakosság magánberuházásainak javára.) (4. táblázat)

\section{TÁBLÁZAT}

Az ipari beruházások összetételének változása

a beruházók szerint Budapesten, \%

(Changes in the composition of industrial investments

in Budapest, \%)

\begin{tabular}{lccc}
\hline & 1980 & 1985 & 1989 \\
\cline { 2 - 4 } 1. Központi & 48,5 & 38,9 & 27,1 \\
2. Vállalati & 47,9 & 50,6 & 59,1 \\
3. Lakossági magán beruházások & 3,6 & 10,5 & 13,8 \\
\hline
\end{tabular}

Forrás: Budapesti Statisztikai Évkönyv, 1989.

1. Central

2. Enterpreneurial/company

3. Private investments of the population 
Melyik - az elóbb említett - kettó közül?

Mint az elốbbiekben már utaltam rá, lehet látni az új gazdasági struktúra kialakulásának, a szolgáltató szektor - és ezen belül is a nem anyagi jellegũ szolgáltatások - elổretörésének bizonyos jeleit, elsổsorban Budapesten. Kétségtelen, hogy a mozgékony kisvállalkozások és a helyét megfontoltan keresố külföldi tốke szívesebben fektet be a szolgáltatások területén, mint az iparban.

Mindezeket figyelembe véve, a magam részérốl inkább annak az állásfoglalásnak adnék hangot, mely szerint a magyar gazdaság jelenleg nincs a posztindusztriális szakaszban, iparának visszaszorulását elsôsorban a szocialista gazdaság fejlôdésképtelenségéhez, és az átmenet nehézségeihez lehet kötni. Állításomat arra alapozom, hogy a posztindusztriális korszak a legfejlettebb piacgazdaságokat érte el és hatotta át, melyekben az ipar a legkorszerúbb termékeket állította elố, eladhatatlan mennyiségben. Véleményem összhangban van azokéval, akik szerint ezekben a fejlett országokban sem az ipar eltủnése lett a változások folyománya, hanem a korszerú ágazatok elốretörése következett be a tradicionális ágazatok rovására, illetve ennek alapján ment végbe az ipar térbeli átrendeződése.

Magyarország ipara meglehetổsen közepes fejlettségũ , szerkezetében csak igen kevés nyoma van a csúcstechnológia alkalmazásának, uralkodóak még a tradicionális ágazatok, a térbeli átrendezôdés még nem következett be.

Elổrelátható, hogy a külföldi tốke fokozódó beáramlása, a gazdaság — lassú - stabilizálódása az ipart is meg fogja erốsíteni. Az ipar fejlôdése azonban már nem a korábbi nyomon fog haladni, de nem is a legfejlettebb országét fogja követni. Magyarország nyilván a fejlett világ peremére fog kerülni; ide az az ipar jut el, amelyik kiszorul a legfejlettebb országok gazdaságából. Még ehhez a fejlốdéshez is hiányosak azonban a hazai feltételek. A rendelkezésre álló munkaerố jórésze - mely egyébként már közel sem olyan olcsó, mint a korábbi években képzetlen és tanulatlan, képtelen a gyors váltásra. Az infrastruktúra elmaradott, hiánya különösen vidéken teszi úgyszólván lehetetlenné az új iparok letelepedését. Magyarország mindezek mellett is egyelổre tartani tudja korábbi elổnyét a többi kelet-európai országgal szemben, sốt - viszonylagos belsố stabilitásával - ezt még növelni is képes.

\section{Az ipar várható szerepe a területfejlesztésben}

A területfejlesztés alapvetố célja a kiegyensúlyozott területi fejlôdés elôsegítése. Ennek érdekében két fớ területre koncentrálja erôfeszítéseit: a gazdaságfejlesztésre (éspedig közvetlenül a gazdaságfejlesztésre vagy a gazdasági fejlổdés feltételeinek megteremtésére), illetve a természeti értékek megổrzésére.

Nyilvánvaló, hogy a területfejlesztési politika a gazdaságnak azt az elemét emeli ki, amely éppen megfelel az ország gazdasági fejlettségének. A fejlett tớkés országok II. világháború utáni területfejlesztésében majdnem olyan központi helyet töltött be a ,,centralizáltan decentralizált" iparfejlesztés, mint ahogyan azt a szocialista országok területfejlesztési programjaikban meghirdették (de kevésbé valósították meg). A fejlett piacgazdaságok késốbbi területfejlesztésének gazdaságfejlesztési stratégiájában ugyan az ipar veszített jelentôségébốl, de korántsem 
tû̉nt el (speciális válságterületek, bezárással fenyegetố vállalatok, az újonnan letelepedổ vállalatok állami támogatása; az innováció-orientált területi politika az ipari folyamatok és az új termékek térbeli elterjedésének segítésére). Ez utóbbi programok félsikere és kis hatékonysága miatt helyezôdött át a területfejlesztésben a hangsúly a belsố erôforrásokra támaszkodó programok támogatására, illetve az új növekedési centrumok létrehozására (innovációs, ipari, technológiai, tudományos parkok építése, technopoliszok fejlesztése). Ezek a programok nem építenek explicite az iparfejlesztésre, de nem is zárják ki annak lehetôségét.

Valójában erról van szó a magyar célok (a gazdaság átalakításának támogatása a válságövezetekben, a centrum - - periféria feszültségek enyhítése, önerôs fejlổés, adottságokon alapuló fejlesztés, a határmenti együttmúködés támogatása stb.) eseteiben is - az ipar lehet (és lesz) a területfejlesztés egyik eleme.

A területfejlesztésnek azonban alapvetốen megváltoztak a lehetốségei és az eszközei az iparfejlesztés elôsegítésére. A redisztribuciós rendszer szúkülése elméletileg is lecsökkenti a kormány beavatkozási lehetốségeit az erốforrások átrendezésében. (Mindenesetre tény, hogy ezidáig sem a területfejlesztés érdekében csoportosították át a beruházásokat.)

$\mathrm{Az}$ eladósodott ország gazdasága válságban van, az új értékek termelése csökken. Ebben a helyzetben a területfejlesztésre fordítható keretek még inkább korlátozottak (1991-ben mindössze 1,5 Md Ft volt).

A vállalatok önállósodásával, az állami szektor visszaszorulásával is csökken az állam közvetlen beavatkozási lehetôsége a gazdasági folyamatokba (pl. olyan intézkedések rákényszerítése a vállalatokra, melyek sértik azok érdekeit).

Ugyanakkor - a válság kiszélesedése folytán - az ország egyre nagyobb térségei igénylik az azonnali beavatkozást (a növekvổ munkanélküliség okozta feszültségek), ez — figyelemmel a területfejlesztésre fordítható szứkös forrásokra - úgyszólván lehetetlenné tesz bármiféle hosszútávú gondolkodást, tervezést (a feladat: munkahelyteremtés bármi módon és azonnal).

Megítélésem szerint a területfejlesztés teendôi négy fớ körbe sorolhatók (ezek mind egyszerre jelentenek célokat és térségeket is), melyek keretében az ipar különbözố szerepeket fog betölteni.

\section{A térbeli polarizálódással szemben ható területfejlesztési program}

Ez elsôsorban olyan hálózati infrastruktúra-fejlesztést jelent, melynek révén az ország elmaradottabb területei eredményesebben kapcsolódhatnak bele az ország vérkeringésébe, a perifériák szorosabban kötődhetnek a centrumokhoz. Ennek a fejlesztésnek a része lehet az a széleskörữ oktatási és átképzési program, mely a fejletlenebb területek aktív népességét is alkalmassá teheti arra, hogy a korszerú gazdaságban munkát találjon. Ez a program nem irányul közvetlenül az iparfejlesztésre, de hozzájárul azoknak a feltételeknek a létrehozásához, melyek elốnyössé tehetik az ipar letelepedését és mứködését.

A teruleti szélsóségeket csökkentô, a súlyos területi feszültségeket csillapíto teriletfejlesztési programok

Ennek a célnak kétféle megközelítését lehet számba venni: a gazdaság fejlesztése, stabilizálása a térségen belül, illetve a népesség mobilizálódásának (elingázás, elvándorlás) elốsegítése. 
Az ipar - munkahelyteremtổ szerepével - fontos része a helyi gazdaságfejlesztésnek. Elsốsorban a helyi központú, korszerũ vállalkozásokat kell segíteni, mert ezek meggyökeresedése és innovatív jellege hosszú távon is hatékonyabban mozdítja elổ a térség fejlődését.

\section{A kistérségi integrációs törekvések támogatása}

E fejlesztési irány gyakorlati megvalósítása igen kívánatos lenne, a fejlett nyugat-európai országokban is jó eredményeket értek el vele. Magyarországon - legalábbis egyelổe - még alig találkozhatunk ilyen jellegũ törekvésekkel. A helyi közösségek csak most ismerik fel és fogalmazzák meg saját édekeiket és kísérelnek meg valódi közösségekké válni. Ez a folyamat azonban sokkal inkább a korábban adminisztratív módszerekkel összekényszerített településegyüttesek szétválására hat, semmint a hasznos kistérségi integrációra. Az önkormányzatoknak elốbb át kell érezniök, hogy számos égetố problémájukat nem képesek saját erốbốl megoldani, és csak ennek felismerését követôen fognak - érdekeiket követve - a szomszédokhoz fordulni, kooperációt kínálva, segítséget várva.

Egy-egy nagyobb méretú iparvállalat, vagy a kis- és középvállalkozások ipari körzetté (erre példák vannak Olaszországban és Franciaországban) formálódása jelentôs mértékben hozzájárulhat a kistérségek célszerú integrálódásához. Ezt a folyamatot azonban aligha lehet a területfejlesztés eszközeivel támogatni.

\section{Növekedési centrumok kialakítása}

A növekedési centrumok (innovációs, ipari, tudományos parkok, technopoliszok) tervei már nem arra, az idốk folyamán illúziónak bizonyult elméletre épülnek, hogy egy-egy központ külsổ erôvel történô fejlesztésének hatásai késốbb automatikusan szétterjednek a központ környezetében. A fejlesztés kifejezetten a centrumok érdekében megy végbe, abban a reményben, hogy a megfelelổ feltételeket létrehozva, az ember elérheti innovatív, alkotó képessége maximumát.

A növekedési centrumok a kutatás - fejlesztés - csúcstechnológián alapuló ipari termelés, és az ezeket a tevékenységeket magas színvonalon kiszolgáló tercier szektor együttesét foglalják magukba.

A területi rendszer logikájával nem ellentétben, hanem azzal egyirányban haladva, kell segíteni a régi növekedési centrumok fejlesztését, az új növekedési centrumok kialakulását, annak szem elốtt tartásával, hogy ezek kapcsolódjanak bele a nemzetközi vérkeringésbe, a fejlett európai városhálózatba. Erre jelenleg elsősorban Budapestnek van esélye. Sikere esetén elképzelhetổ, hogy Magyarország ezen keresztül olyan elônyök birtokába juthat, melyekbôl (például egy területileg differenciált adórendszer beiktatásával) a korábbiaknál többet profitálhatnának az ország elmaradott térségei is. Nem kétséges egyben, hogy a növekedési centrumok fejlesztésének következményeként felgyorsul a térbeli differenciálódás is. 


\section{Irodalom}

Barta Gy. (1987) A termelés térbeli szétterjedése és a szervezet területi centralizációja a magyar iparban, Tér és Társada lom, 2.

Barta Gy. (1990) Centrum-periféria folyamatok a magyar gazdaság területi fejlôdésében? Tóth J. (szerk.) Tér-IdôTársadalom, MTA. RKK, Pécs.

Gyenei M. (1990) Feszültségoldó kampányok a településpolitikában, Kandidátusi értekezés.

Inzelt A. (1988) Rendellenességek az ipar szervezetében. Idôszerũ Közgazdasági Kérdések, Budapest, Közgazdasági és Jogi Könyvkiadó.

Kornai J. (1989) Régi és új ellentmondások és dilemmák, Gyorsuló Idó, Budapest, Magvetố.

Scott, A.J. (1988) Metropolis: from the division of labor to urban form, University of California Press.

Stöhr, W.B. (1987) A területfejlesztési stratégiák változó külsố feltételei és új koncepciói, Tér és Társadalom, 1.

Voszka É. (1988) Reform és átszervezés a nyolcvanas években, Idószerü Közgazdasági Kérdések, Budapest, Közgazdasági és Jogi Könyvkiadó.

Ipari és kereskedelmi koncepció, Az 1988-1990-es évek értékelése, IKM, Budapest, 1991.

Ipar- és kereskedelempolitikai koncepció 1991-1994, IKM, Budapest, 1991. 


\section{THE ROLE OF INDUSTRY IN THE ,,SOCIALIST” ECONOMIC- AND REGIONAL DEVELOPMENT POLICY}

The situation was easily assessable, and the tasks were clear for the regional experts of the socialist era: industry (autarchy and over-emphasized defence objectives gave priority to heavy industry) was the engine of economic development policy, which was also based on industrial development. It must be added, that little attention was paid on details. In stead of developing a structurally well-balanced and efficient regional policy which meets the characteristics of different regions and then can be fitted into an organic regional economy, the primary objective was to increase the number of industrial workplaces.

Extensive approach, which put the sign of equality between development and physical extension, got into trouble already in the 1970 s. How can the decreasing number of industrial employees, and the decreasing pace of the development of industrial production be interpreted? These were the signs of the crisis of socialism, and the exhaust of resources, the decrease of free labour and the lack of capital became characteristic.

Besides all these phenomena, industry had preserved its special role in regional development policy all the time, though the importance of industry was handled and interpreted in a more tinged way in the whole society.

The present situation of industry is characterized by overall decline: industrial capacities are becoming limited, the number of people dismissed from industry is unstoppably increasing, the extensive markets of our industrial products are lost, and new markets are difficult to find, industrial production is decreasing both in absolute terms and also as compared to the national income.

What is the present case then now? What we are faced is the temporary crisis of industry, which follows from the transitional character of our socio-economic development? Or probably, Hungary has also got into the phase of post-industrial development, where industry loses its previous role?

Answering these questions is indispensible to elaborate the new regional-development policy, because regional development always has to use the most modern and dynamic elements of socio-economic development. 